\title{
The effect of level of food intake on the incorporation of acetate into lipids and its distribution among various tissues in sheep
}

\author{
BY T. E. BROAD AND M. J. ULYATT \\ Applied Biochemistry Division, DSIR, \\ Palmerston North, New Zealand
}

(Received 7 September 1979 - Accepted 4 January 1980)

I. Romney wethers were infused intravenously with $\left[2-{ }^{14} \mathrm{C}\right] \mathrm{acetate}$ for $5 \mathrm{~d}$ during which time they were given, three/group, different amounts of lucerne (Medicago sativa L.) chaff. The groups and the amounts fed were: $\mathrm{MS}, 700 \mathrm{~g}$ but starved during the infusion period; $\mathrm{M}, 700 \mathrm{~g}$ throughout; $1 \cdot 3 \mathrm{M}, 950 \mathrm{~g}$ throughout; $\mathrm{AL}$, ad lib. throughout.

2. On day 4 of the infusion, the oxygen consumption, and production rate of expired ${ }^{14} \mathrm{CO}_{2}$ were measured. At the end of the infusion, the sheep were killed and the amounts of radioactivity in the lipids of various tissues were determined.

3. Significant differences were present between the specific activities of the tissues. The internal adipose tissues generally had higher specific activities than subcutaneous or intermuscular adipose depots. Although the intramuscular lipid also was highly labelled, the liver had the greatest specific activity.

4. Food intake did not significantly affect this pattern of specific activity of labelling of the tissues.

5. While most of the total lipid radioactivity was present in adipose tissues, the proportion in the liver increased to $40 \%$ during starvation.

Acetate is a major precursor of lipid in ruminants (Ballard et al. 1969; Bauman, 1976; Prior, 1978 ). Using sheep killed 15 or $30 \mathrm{~min}$ after receiving a single dose of $\left[\mathrm{I}^{14} \mathrm{C}\right]$ acetate, Ingle et al. (1972) found radioactivity distributed predominantly in adipose tissue with only $8 \%$ in the liver and gastrointestinal tract. Differences between adipose tissue sites, in terms of acetate incorporation into fatty acids on a tissue weight basis, were apparent. It was concluded that adipose tissue was the predominant site of fatty acid synthesis in vivo and that the differences between the adipose tissue sites reflected their differing lipogenic activities (Ingle et al. 1972).

The purpose of our study was twofold. It was to observe the pattern of labelling of the lipids in various sites of sheep that had been infused with $\left[2^{-14} \mathrm{C}\right]$ acetate for $5 \mathrm{~d}$ at which time we considered it more likely that a steady-state condition had been reached with the isotope. Secondly, it was our aim to study the effects of food intake on that pattern of radioactivity distribution.

\section{EXPERIMENTAL}

\section{Animals, feeding regimens and management}

Twelve Romney wethers, approximately I year old, that were raised on ryegrass (Lolium perenne L.) clover (Trifolium repens $\mathrm{L}$.) pasture from weaning, were shorn and dosed with an anthelmintic. Their mean ( \pm SE) live weight was $37 \cdot 2 \pm 0.44 \mathrm{~kg}$. They were then housed in metabolic crates indoors, mean $( \pm S E)$ room temperature $17 \pm \mathrm{I}^{\circ}$, under artificial light for approximately $10 \mathrm{~h} / \mathrm{d}$.

The animals were randomly assigned to four feeding groups of three/group, and given lucerne (Medicago sativa L.) chaff in weighed daily portions at 09.00 hours. Access to water and a mineral salt lick was unrestricted. The amounts of lucerne chaff given to each group 
were as follows: two groups (MS, M) were given $700 \mathrm{~g} / \mathrm{d}$ which was estimated as the maintenance requirement (Agricultural Research Council, 1965); the third group was given $950 \mathrm{~g} / \mathrm{d}$, or $\mathrm{I} \cdot 3 \times$ maintenance $(\mathrm{I} \cdot 3 \mathrm{M})$; and the fourth group was fed ad lib. (AL), i.e. they were offered $1200 \mathrm{~g} / \mathrm{d}$ and the actual intake was calculated by subtracting the amount of food refused/d. The animals were maintained on these feeding regimens for $46 \mathrm{~d}$ during which time they were weighed twice weekly and trained to stand quietly in an open-circuit respiration hood.

On day 44 the jugular veins of each sheep were cannulated and on day 47 the sheep were moved, in pairs selected randomly, into a separate room where they were infused for $5 \mathrm{~d}$ with $\left[2-{ }^{14} \mathrm{C}\right]$ acetate. During this infusion period the feeding regimen described previously was continued but with two exceptions: one of the groups of sheep given $700 \mathrm{~g}$ lucerne chaff/d was starved during the whole infusion period (MS) but still had unrestricted access to water and a mineral salt lick; and on day 4 of the infusion when all sheep were placed in the respiration hood for a $4 \mathrm{~h}$ period (08.00-12.00 hours) the three groups of sheep that were fed during the infusion, then received lucerne chaff every hour in amounts that were one-twentyfourth of their daily allowance. The mean ( \pm SE) live weights of the sheep in the MS, $M, 1 \cdot 3 \mathrm{M}$ and $\mathrm{AL}$ groups at the commencement of the infusion were $34.7 \pm 0 . \mathrm{I} 2 \mathrm{~kg}$, $34 \cdot 2 \pm 0.06 \mathrm{~kg}, 39 \cdot 2 \pm \mathrm{I} \cdot \mathrm{I} \mathrm{kg}$ and $39 \cdot 3 \pm \mathrm{I} \cdot 2 \mathrm{~kg}$ respectively.

\section{Experimental procedures}

The left jugular vein of each sheep was infused for $5 \mathrm{~d}$ at a daily rate of approximately $56 \mathrm{ml}$ $\left[2{ }^{14} \mathrm{C}\right.$ ]acetate acid (sodium salt; $\mathrm{I} \cdot 78 \mu \mathrm{Ci} / \mathrm{ml}$ ), in physiological saline ( 9 g sodium chloride/1) containing I mmol sodium acetate carrier. The infusate was sterilized by filtration and maintained at $4^{\circ}$ throughout the infusion period. The total mean $( \pm \mathrm{SE})$ amount of radioactivity (disintegrations/min $\left(\times 10^{-6}\right)$ ) in $\left[{ }^{14} \mathrm{C}\right]$ acetate infused was I $188.0 \pm 77.7$.

During the infusion, the total urine and faeces was collected and disposed of and the expired ${ }^{14} \mathrm{CO}_{2}$ was expelled to the exterior by a fan. Blood samples were collected from the cannulated right jugular vein at $8 \mathrm{~h}$ and then at $24 \mathrm{~h}$ intervals after the start of the infusion, the cannula then being flushed with heparinized saline.

On day 4 of the infusion the sheep were placed individually in an open-circuit respiration hood for $4 \mathrm{~h}$ and their rates of oxygen consumption, total $\mathrm{CO}_{2},{ }^{14} \mathrm{CO}_{2}$, methane and heat production were measured (Ulyatt et al. 1973).

At the end of day 5 of the infusion the sheep were injected with a lethal dose of Nembutal (Abbott Laboratories (NZ) Ltd, Naenae, NZ), exsanguinated, skinned and eviscerated. The following samples of tissue were removed by dissection into plastic bags, weighed and placed on ice: all adipose tissue associated with the viscera, all adipose tissue from the internal surface of the abdominal and pelvic cavity, all intermuscular adipose tissue surrounding the internal and external abdominal muscles, all subcutaneous adipose tissue overlying the scapular, sternum (brisket) and rump, i.e. within the area defined by a line linking the two tubers coxae anteriorly to the two lateral ischiatic tubers posteriorly, the muscles biceps femoris, triceps brachii and longissimus dorsi, and the liver.

\section{Analytical methods}

The tissue samples were taken off ice, minced and two $\mathrm{I} 0 \mathrm{~g}$ portions were removed. The total lipids were then extracted using Io vol. chloroform-methanol $(2: \mathrm{I}, \mathrm{v} / \mathrm{v})$ (Folch et al. 1957), weighed, dissolved in chloroform and stored at $-20^{\circ}$ until subjected to radioactive counting and thin-layer chromatography (TLC). The lipid-extracted residue was dried at $90^{\circ}$, weighed and portions were taken in duplicate for total nitrogen determination by the Kjeldhal procedure, and for radioactive counting.

TLC was used to determine the distribution of radioactivity among the major classes of 
lipids extracted from the tissues. The lipid extracts and appropriate standards were applied to silica gel $G$ plates which were then developed with hexane-diethyl ether-acetic acid $(85: 15: 1$, by vol); the spots were detected with iodine vapour and then scraped into scintillation vials for radioactive counting.

Expired ${ }^{14} \mathrm{CO}_{2}$ was trapped in barium hydroxide which was then filtered, washed, dried, weighed and subjected to radioactive counting.

Radioactive samples were counted using a liquid-scintillation spectrometer (Isocap 300; Searle Analytical Inc., Des Plaines, Illinois, USA). Lipid samples to be counted, were dried, dissolved and counted in $10 \mathrm{ml}$ toluene containing $40 \mathrm{mg}$ Omnifluor (New England Nuclear, Boston, USA)/ml. Dried lipid-extracted residues were solubilized with I ml Protosol (New England Nuclear, Boston, USA) and then counted in toluene-Omnifluor. Spots from TLC plates and radioactive barium carbonate were counted in emulsions produced by the addition of $2 \mathrm{ml}$ water and $10 \mathrm{ml}$ Triton X-I00-toluene-Omnifluor $(\mathrm{I}: 2, \mathrm{v} / \mathrm{v})$.

\section{Calculations}

The lipid weight of adipose tissues and muscle (Table 3) was calculated from regression equations determined from a growth study of Romney sheep (Broad \& Davies, I980). In that study which extended from foetal lambs weighing $3 \mathrm{~g}$ to mature 5-year-old sheep, the weight of lipid was found to increase at a constant linear rate relative to body-weight. The regression equations derived in that study were therefore considered to be relevant to the present investigation. The following regressions were used to calculate the total side adipose lipid weight $\left(Y_{\mathrm{AL}}\right)$ and the total side muscle lipid weight $\left(Y_{\mathrm{ML}}\right)$ respectively of a $33.78 \mathrm{~kg}$ sheep (the average body-weight (BW) of those used in this study):

$$
\log _{e} Y_{\mathrm{AL}}=-18.249+2.460 \times \log _{e} \mathrm{BW}, \quad \log _{e} Y_{\mathrm{ML}}=-7.898+\mathrm{I} \cdot 269 \times \log _{e} \mathrm{BW} .
$$

The total body measurements were obtained by multiplying the sum of the transformed total side values by 2 . Further regressions of adipose lipid weights for different fat depots from the fore- and hind-quarters of sheep on total side lipid (TSL), were then used to estimate the total weights of different adipose lipids in sheep. The total adipose depot lipid weights were thus calculated from $2 \times$ (fore-quarter depot lipid weight + hind-quarter depot lipid weight). The regressions used are presented in pairs for each depot, with the fore-quarter first followed by hind-quarter in parentheses: subcutaneous adipose lipid, $\log _{e} Y=5.51 \mathrm{I}+$ I.5I5 $\times \log _{e}$ TSL, $\quad\left(\log _{e} Y=-3.896+1.286 \times \log _{e}\right.$ TSL); intermuscular adipose lipid, $\log _{e} Y=-2.684+\mathrm{I} \cdot \mathrm{I} 6 \mathrm{I} \times \log _{e} \mathrm{TSL},\left(\log _{e} Y=-3 \cdot \mathrm{I} 87+\mathrm{I} \cdot 089 \times \log _{e} \mathrm{TSL}\right) ;$ internal cavity adipose lipid, $\log _{e} Y=-2 \cdot 24 \mathrm{I}+0 \cdot 786 \times \log _{e} \mathrm{TSL},\left(\log _{e} Y=-2 \cdot 606+\mathrm{I} \cdot 089 \times \log _{e} \mathrm{TSL}\right)$.

\section{RESULTS}

\section{Plasma radioactivity}

Fig. I shows that in the group of sheep given $700 \mathrm{~g}$ lucerne chaff/d, the amount of radioactivity in the plasma increased curvilinearly as a function of the period of infusion. Similar results were obtained for the other groups of animals. This increase in radioactivity was paralleled by an increase in the specific activity of plasma lipid (Fig. 1). Thus the measurements made using the respiration hood, as well as the subsequent determinations of the specific activity of the tissue lipids, were made when the rate of change of radioactivity in plasma lipids was small. It is therefore likely that the labelled plasma and tissue lipid pools were close to a steady-state condition. 


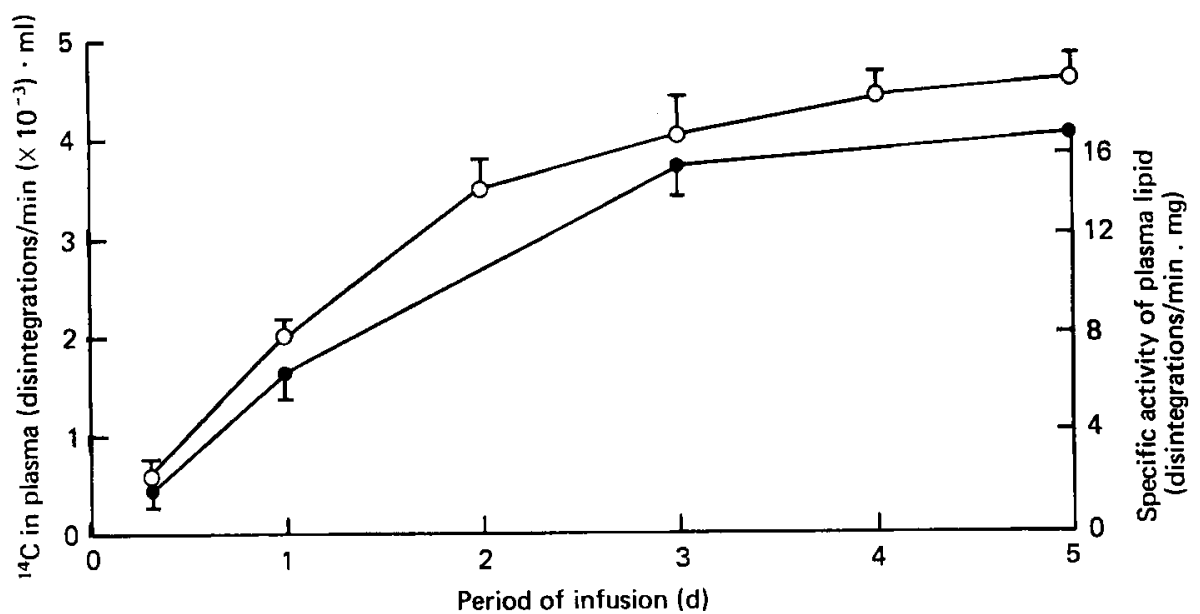

Fig. I. Effect of period of infusion (d) on the level of radioactivity (disintegrations $/ \mathrm{min}\left(\times 10^{-3}\right)$ per $\mathrm{ml}$ ) and specific activity of labelling of lipid (disintegrations/min per $\mathrm{mg}$ ) in plasma of sheep. $\mathrm{O}-\mathrm{O},{ }^{14} \mathrm{C}$ in plasma; - - , specif.c activity of plasma lipid. The points are mean values, with their standard errors represented by vertical bars.

Table I. Food intake, oxygen consumption and expiratory ${ }^{14} \mathrm{CO}_{2}$ production rate of sheep in the respiration hood during the intravenous infusion of $\left[2-{ }^{14} \mathrm{C}\right]$ acetate

(Mean values with their standard errors for three sheep/group)

\begin{tabular}{|c|c|c|c|c|c|c|c|c|}
\hline \multirow[b]{2}{*}{ Feeding regimen* } & \multicolumn{2}{|c|}{$\begin{array}{c}\text { Live weight } \\
(\mathrm{kg})\end{array}$} & \multicolumn{2}{|c|}{$\begin{array}{l}\text { Food intake } \\
\text { during infusion } \\
(\mathrm{g} / \mathrm{d})\end{array}$} & \multicolumn{2}{|c|}{$\mathrm{O}_{2}$ consumption } & \multicolumn{2}{|c|}{$\begin{array}{c}\text { Expired } \mathrm{CO}_{2} \\
\text { specific activity } \\
\text { (disintegrations/ } \\
\text { min per mg C per min) }\end{array}$} \\
\hline & Mean & SE & Mean & SE & Mean & SE & Mean & SE \\
\hline $\begin{array}{l}700 \mathrm{~g} \text { then starvation } \\
\text { ing infusion }\end{array}$ & $28 \cdot 7$ & 0.54 & 0 & & 181 & $3 \cdot 8$ & 995 & $152 \cdot 9$ \\
\hline oo g throughout & $30 \cdot 6$ & 0.78 & 700 & $40 \cdot 4$ & 332 & 10.9 & 612 & $60 \cdot 0$ \\
\hline$\Lambda, 950 \mathrm{~g}$ throughout & 33.6 & 0.80 & 950 & $54 \cdot 8$ & 361 & $27 \cdot 7$ & 549 & $46 \cdot 6$ \\
\hline Ad lib. throughout & $34 \cdot 8$ & 0.60 & 547 & $110 \cdot 2$ & 344 & $21 \cdot 6$ & 485 & $81 \cdot 2$ \\
\hline
\end{tabular}

\section{Performance of animals in metabolic hood during infusion}

The effect of food intake on the live weight, $\mathrm{O}_{2}$ consumption and specific activity of expired ${ }^{14} \mathrm{CO}_{2}$ of all groups of sheep is shown in Table 1 . The relatively low $\mathrm{O}_{2}$ consumption but high specific activity of expired ${ }^{14} \mathrm{CO}_{2}$ is a consistent and expected result of starvation of the MS group.

The food intake of the $\mathrm{AL}$ group decreased during the infusion and when placed in the respiration hood, an effect that is also reflected in both their $\mathrm{O}_{2}$ consumption and ${ }^{14} \mathrm{CO}_{2}$ specific activity (Table 1 ). However this aberrant feeding pattern apparently had little effect on their live weight which remained significantly higher than the $\mathrm{M}$ group $(P<0.01)$ even though their intake dropped to submaintenance levels.

Although differences $(P<0.0 \mathrm{I})$ in live weight were apparent between the groups (Table 1$)$ the live weights of all groups decreased $(P .<0.05)$ during the experiment from an initial weight of $37.2 \pm 0.44 \mathrm{~kg}$. There were no significant differences $(P<0.05)$ between groups in the wet weights of the livers, hearts or any of the adipose tissues or muscles taken after slaughter. 
Table 2. The specific activity of lipid (disintegrations/min per $g$ lipid) in various tissues of sheep infused with $\left[2-{ }^{14} \mathrm{C}\right]$ acetate and given different amounts of lucerne (Medicago sativa L.) chaff

(Mean values for three sheep/group $\nmid$ )

Feeding regimen*

\begin{tabular}{|c|c|c|c|c|c|}
\hline \multirow[b]{2}{*}{ Adipose tissues $\uparrow$} & & \multirow[b]{2}{*}{ Tissue means } \\
\hline & MS & $\mathbf{M}$ & $\mathrm{I} \cdot 3 \mathrm{M}$ & $\mathbf{A L}$ & \\
\hline Visceral & $\begin{array}{c}1044 \\
(3 \cdot 019)\end{array}$ & $\begin{array}{c}1795 \\
(3 \cdot 254)\end{array}$ & $\begin{array}{c}3340 \\
(3 \cdot 524)\end{array}$ & $\begin{array}{c}700 \\
(2 \cdot 845)\end{array}$ & $(3 \cdot 161)$ \\
\hline Internal cavity & $\begin{array}{c}903 \\
(2 \cdot 956)\end{array}$ & $\begin{array}{c}3548 \\
(3550)\end{array}$ & $\begin{array}{c}6108 \\
(3 \cdot 786)\end{array}$ & $\begin{array}{c}1756 \\
(3 \cdot 245)\end{array}$ & \\
\hline Intermuscular & $\begin{array}{c}928 \\
(2 \cdot 968)\end{array}$ & $\begin{array}{c}2198 \\
(3.342)\end{array}$ & $\begin{array}{c}3678 \\
(3.566)\end{array}$ & $\begin{array}{c}494 \\
(2 \cdot 694)\end{array}$ & \\
\hline \multicolumn{6}{|l|}{ Subcutaneous } \\
\hline Brisket & $\begin{array}{c}1915 \\
(3.282)\end{array}$ & $\begin{array}{c}2052 \\
(3 \cdot 312)\end{array}$ & $\begin{array}{c}3170 \\
(3.501)\end{array}$ & $\begin{array}{c}2182 \\
(3.339)\end{array}$ & $(3 \cdot 359)$ \\
\hline Rump & $\begin{array}{c}937 \\
(2 \cdot 972)\end{array}$ & $\begin{array}{c}1317 \\
(3 \cdot 120)\end{array}$ & $\begin{array}{c}2345 \\
(3 \cdot 370)\end{array}$ & $\begin{array}{c}520 \\
(2 \cdot 716)\end{array}$ & $(3 \cdot 045)$ \\
\hline Scapular & $\begin{array}{c}1010 \\
(3.004)\end{array}$ & $\begin{array}{c}1175 \\
(3.070)\end{array}$ & $\begin{array}{c}2599 \\
(3.415)\end{array}$ & $\begin{array}{c}544 \\
(2 \cdot 736)\end{array}$ & $(3.056)$ \\
\hline \multicolumn{6}{|l|}{ Muscle $\dagger$} \\
\hline Biceps femoris & $\begin{array}{c}2656 \\
(3 \cdot 424)\end{array}$ & $\begin{array}{c}3562 \\
(3.598)\end{array}$ & $\begin{array}{c}2060 \\
(3 \cdot 314)\end{array}$ & $\begin{array}{c}1214 \\
(3.084)\end{array}$ & $(3 \cdot 355)$ \\
\hline Triceps brachii & 2525 & 2013 & 2204 & 1622 & \\
\hline & $(3 \cdot 402)$ & $(3 \cdot 304)$ & $(3 \cdot 343)$ & $(3.210)$ & $(3 \cdot 315)$ \\
\hline Longissimus dorsii & 2813 & 2785 & 1953 & 1355 & (2.20) \\
\hline Liver & $\begin{array}{l}(3.449) \\
53655 \\
(4 \cdot 730)\end{array}$ & $\begin{array}{l}(3 \cdot 445) \\
46455 \\
(4 \cdot 667)\end{array}$ & $\begin{array}{l}(3 \cdot 29 I) \\
27084 \\
(4 \cdot 433)\end{array}$ & $\begin{array}{l}(3 \cdot 132) \\
22223 \\
(4 \cdot 347)\end{array}$ & $(4 \cdot 544)$ \\
\hline
\end{tabular}

Least significant difference between log. tissue means (over diets) $\ddagger=0.225$.

Least signiscant difference between log. feeding regimen means (over sites) $\ddagger=0.553$.

- MS, $700 \mathrm{~g}$ then starvation during infusion; $\mathrm{M}, 700 \mathrm{~g}$ throughout experiment; $1 \cdot 3 \mathrm{M}, 95 . \mathrm{g}$ throughout experiment; $\mathbf{A L}$, ad lib. throughout experiment.

$\dagger$ Logarithmic transformation needed to make variation homogeneous: log means given in brackets.

$\ddagger$ At $5 \%$ level of probability: only log values given.

\section{Distribution of radioactivity in tissues of sheep}

Over $90 \%$ of the radioactivity from $\left[2^{-14} \mathrm{C}\right]$ acetate in the tissues analysed was water soluble, presumably most of this being free acetate distributed throughout the blood and extracellular fluid components of the tissues. Approximately $5 \%$ of the total radioactivity was present in the lipid fraction of the extracted tissue samples, and negligible amounts $(<0.3 \%)$ were associated with the insoluble residue remaining after lipid extraction which was probably comprised largely of protein.

The specific activity of $\left[2^{-14} \mathrm{C}\right]$ acetate incorporation into the lipid fraction of tissues from various sites is shown in Table 2. On a lipid basis, the greatest incorporation of radioactivity was clearly into the liver. However, the pattern of labelling of the other sites was relatively less well defined (Table 2) but may also be outlined by ranking the tissues from the highest to lowest specific activities as follows: liver; muscles longissimus dorsi and biceps femoris, and brisket (subcutaneous) adipose tissue; triceps brachii, and internal cavity adipose tissue; visceral adipose tissue; intermuscular adipose tissue; rump and scapular (subcutaneous) adipose tissues. The variation between animals was substantial.

TLC of the extracted lipid revealed that the radioactivity was located predominantly in the triglyceride component of adipose tissue and muscles. Whereas approximately $70 \%$ of the radioactivity was present in the triglyceride fraction of liver lipids from the MS group, 
only approximately $20 \%$ of the label in liver lipids of the remaining treatment groups was in triglycerides.

\section{Effect of food intake on the distribution of radioactivity in the tissues of sheep}

Starvation, and feeding up to ad lib. amounts did not significantly $(P<0.05)$ affect the pattern of specific activity of labelling of tissue sites (Table 2), even though the specific activity of $\left[2-{ }^{14} \mathrm{C}\right]$ acetate incorporated into lipid was reduced in the MS and AL groups.

Although the liver lipid had the highest specific activity, Table 3 shows that the liver of an average sheep fed during the infusion of $\left[2-{ }^{14} \mathrm{C}\right]$ acetate contained only $10 \%$ of the radioactivity calculated to be present in its total body lipids. In the starved (MS) sheep, however, the lipid content of the liver increased from $6 \%$ to $20 \%$ of the wet weight, and the proportion of radioactivity in the liver increased to $40 \%$ of that in total body lipids (Table 3 ). Despite this dramatic effect, the greatest proportion of radioactivity was found in total adipose tissue, $54 \%$ and $81 \%$ being found in starved and fed sheep respectively (Table 3 ).

\section{DISC USSION}

\section{Effect of food intake on the pattern of labelling of tissues}

Surprisingly the pattern of specific activity of labelling of the lipids from various tissues was not apparently perturbed by the level of food intake of sheep (Table 2). The over-all drop in the specific activities of all the tissue lipids in the AL group and a similar but less marked effect in the MS group (Table 2), could have been produced by a dilution of the label following increased production of endogenous acetate in starvation (Bergman \& Wolff, 1971) and perhaps by exogenous (dietary) acetate in ad lib. feeding. In contrast, Prior (1978) found that the relative specific activity of lipid increased in the fat of the total carcass, omentum, liver, backfat and perirenal sites in sheep fed ad lib. compared with those fed at maintenance levels. The reason for this apparent discrepancy is unknown.

Starvation produced an expected and dramatic increase in both the specific activity and the total amount of radioactivity incorporated into the liver lipids (Tables 2 and 3). Starvation has long been known to stimulate lipolysis in adipose tissues (Hausberger, I965) and to result, in its early stages, in a fatty liver (Coleman, 1973). It may also be deduced from Table 4 that only $\mathrm{I} \cdot 25 \%$ and $0.84 \%$ of the total radioactivity infused into starved and fed sheep respectively was incorporated into lipid. A similar level of incorporation was also found by Prior (1978).

Although it was not planned, the body-weight of all sheep decreased over the course of the experiment. Thus it would appear that all animals were in a state of negative energy balance. However, the weight of carcass components did not differ significantly $(P<0.05)$ between the groups, even though body-weight differences were apparent between the groups at the time of slaughter (Table I). Therefore, it is likely that the over-all loss of body-weight, as well as the body-weight differences of the groups, was due to changes in the weight of gut contents and was not indicative of the energy balance of the animals.

\section{Pattern of labelling of tissues}

The specific activity of lipid in adipose tissues reported here (Table 2) in which the internal adipose tissues were generally more highly labelled than those at subcutaneous sites, is similar to that reported by Ingle et al. (1972). In a similar study Prior (1978) found no significant differences between the relative specific activities of adipose tissue sites. This apparent discrepancy may be due to the effect of sex as the sheep used in our investigation and that of Ingle et al. (1972) were wethers whereas those used by Prior (1978) were ewes. 


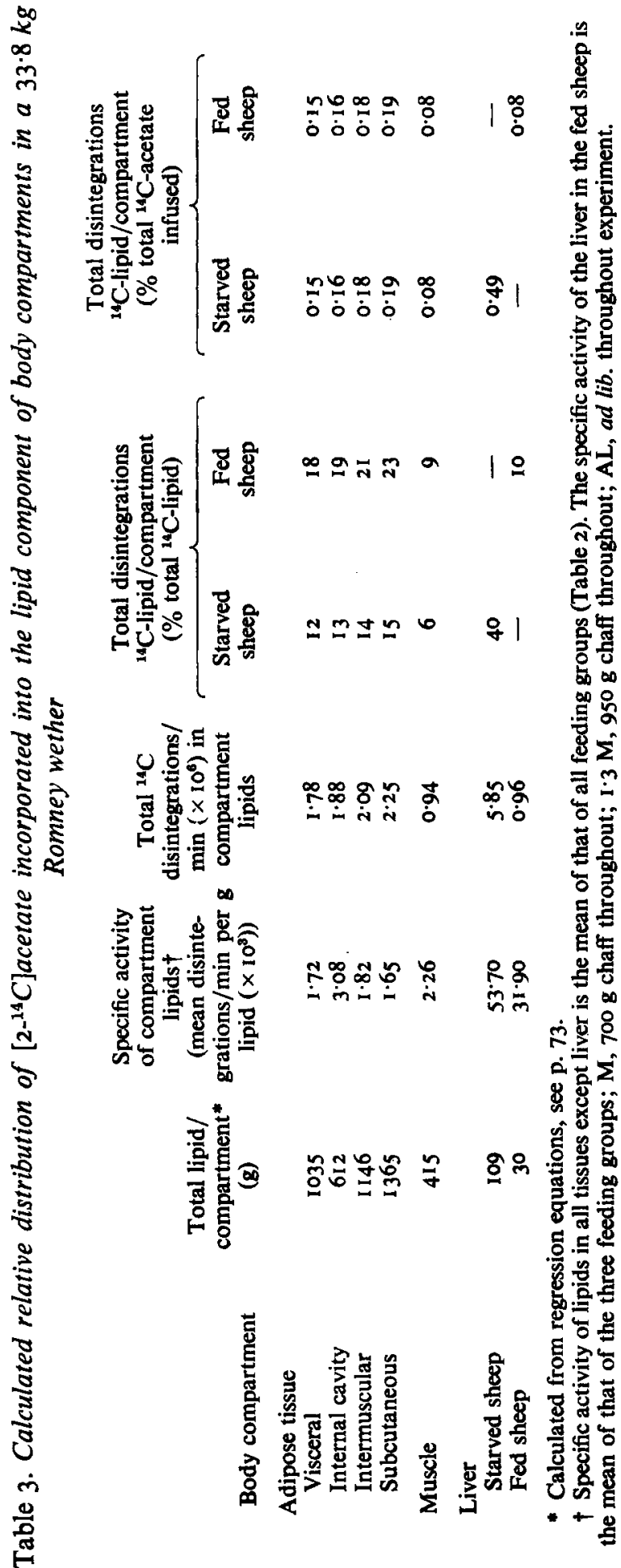


However, we found that there was a significant difference $(P<0.01)$ between the specific activities of subcutaneous adipose tissue sites (Table 2). The reason for this can presently only be the subject of speculation: the more highly labelled brisket site differs markedly from the rump and scapular sites in appearing to be very fibrous. Some lines of fibroblasts in tissue culture undergo transformation to adipocytes (Green \& Kehinde, 1974). The different labelling patterns of these subcutaneous adipose tissues may therefore be due to a relatively greater number of pre-adipocytes in the brisket site.

The proportions of total radioactivity found in liver lipids (Table 3) are higher than those reported by Ingle et al. (1972) who used a single dose of $\left[\mathrm{I}^{14} \mathrm{C}\right]$ acetate, and Prior (1978) who infused various isotopes into sheep for up to $3 \mathrm{~h}$ only. This may be an effect of the much longer period of infusion $(5 \mathrm{~d})$ used in the present study in allowing the specific activity of the acetate pool in the liver to reach a steady-state.

The relatively high specific activity of the muscle lipids (Table 2) and their significant proportion of the total lipid radioactivity (Table 3), have not to our knowledge been previously reported for sheep. The comparatively high specific activity and low mass of this compartment suggests that it has a high rate of turnover and, possibly, synthesis. Kannan et al. (1976) found that in mice the intermuscular adipose tissue and the muscular carcass lipid were more highly labelled after the administration of $\left[\mathrm{U}-{ }^{14} \mathrm{C}\right] \mathrm{glucose}$, and suggested that fat cells associated with the muscular carcass had a major role in lipogenesis. The radioactivity incorporated into muscle lipids in our study was present predominantly in triglyceride and was presumably extracted from fat droplets located within muscle fibres and also from adipocytes intercallated between the fibres. Although the intermuscular adipose tissue in this study had a relatively low specific activity (Table 2) it also contained a substantial proportion of the radioactivity found in total lipid (Table 3 ).

The pattern of specific activity of adipose tissues found here is at variance with the rates of growth of these tissues relative to the growth of the carcass. The growth study by Fourie et al. (1970) of adipose tissues in sheep showed that subcutaneous adipose tissues had a higher allometric coefficient of growth than perinephric fat which in turn had a higher growth rate than intermuscular adipose tissues. In contrast, the specific activity found by us and Ingle et al. (1972) was generally highest in the internal (perirenal) sites and lowest in the subcutaneous depot with the intermuscular adipose tissue occupying an intermediate position. Thus it appears that the rate of turnover of lipid is greatest in the adipose depots which have the slowest relative growth rate. This observation is further supported by the finding of Wright et al. (1974) that the levels of linoleic acid were higher in perinephric than in subcutaneous fat of lambs given a protected-polyunsaturated-fat diet for 4 weeks. When a similar diet was fed for I 4 weeks, no difference in linoleic acid levels of the adipose tissue sites was found (Connolly, 1974).

The relative distribution of radioactivity in the adipose tissues (Table 3 ) is, however, in general accord with the growth rates of the depots as reported by Fourie et al. (1970). Thus the subcutaneous adipose tissue which had a higher growth rate than internal cavity (perirenal) adipose tissue (Fourie et al. 1970), also has a greater proportion of the total lipid radioactivity than the latter (Table 3). Ingle et al. (1972) equated this pattern of distribution with rates of lipogenesis in the different adipose tissues. Although they considered that this pattern could be due to the movement of fatty acids from the site of synthesis to another storage site, this possibility was discounted when it was found that the proportion of total radioactivity recovered from plasma fatty acids was not significantly different at $15 \mathrm{~min}$ compared to $30 \mathrm{~min}$ after a single intravenous dose of $\left[\mathrm{I}^{14} \mathrm{C}\right]$ acetate (Ingle et al. $\mathrm{I} 972$ ). However, although the plasma non-esterified fatty acid pool size is small (less than $2 \%$ of plasma fatty acids) and since the half-life of free fatty acids in this pool is approximately 2 min or less (Newsholme \& Start, 1973), a considerable transfer of radioactive fatty acids 
could occur between different lipid depots without significantly changing the proportion of total radioactivity recovered from the plasma fatty acids. Thus the pattern of distribution of radioactivity may not necessarily reflect the lipogenic capacities of the tissues in which the label is found.

The authors are indebted to Mr V. J. Thomas, Applied Mathematics Division, DSIR, Palmerston North, for his assistance and advice in the statistical analysis of the results. We thank Mrs M. Wong and Mr B. M. Henderson for skilled technical assistance and $\mathrm{Mr}$ A. S. D. King and Mr B. Rogatski for their help in handling and feeding the sheep.

\section{REFERENCES}

Agricultural Research Council (1965). The Nutrient Requirements of Farm Livestock, No. 2, Ruminants. London: HM Stationery Office.

Ballard, F. J., Hanson, R. W. \& Kronfeld, D. S. (1969). Fedn Proc. Fedn Am. Socs exp. Biol. 28,2 I 8.

Bauman, D. E. (1976). Fedn Proc. Fedn Am. Socs exp. Biol. 35, 2308.

Bergman, E. N. \& Wolff, J. E. (1971). Am. J. Physiol. 221, 586.

Broad, T. E. \& Davies, A. S. (1980). Anim. Prod. (In the Press).

Coleman, R. (1973). In Form and Function of Phospholipids, p. 345 [G. B. Ansell, J. N. Hawthorne and R. M. C. Dawson, editors]. Amsterdam-London-New York: Elsevier Scientific Publishing Company.

Connolly, J. F. (1974). Farm Fd Res. 5, 4 I.

Folch, J., Lees, M. \& Sloane Stanley, G. H. (1957). J. biol. Chem. 226, 497.

Fourie, P. D., Kirton, A. H. \& Jury, K. E. (1970). N.Z. Jl agric. Res. 13, 753.

Green, H. \& Kehinde, O. (1974). Cell I, I 13.

Hausberger, F. X. (1965). In Handbook of Physiology, Section 5, Adipose Tissue, p. 519. [A. E. Renold and G. F. Cahill Jr, editors]. Washington, DC: Waverly Press Inc.

Ingle, D. L., Bauman, D. E. \& Garrigus, U. S. (1972). J. Nutr. 102, 617.

Kannan, R., Palmquist, D. L. \& Baker, N. (1976). Biochim. biophys. Acta 431, 225.

Newsholme, E. A. \& Start, C. (1973). Regulation in Metabolism, ch. 5. London: John Wiley.

Prior, R. L. (1978). J. Nutr. 108, 296.

Ulyatt, M. J., Dellow, D. W., Egan, A. R. \& Walker, D. J. (1973). Proc. N.Z. Soc. Anim. Prod. 33, 149.

Wright, D. E., Payne, E. \& Kirton, A. H. (1974). N.Z. Jl agric. Res. 17, 295. 